\title{
Systems entrepreneurship: a conceptual substantiation of a novel entrepreneurial "species"
}

\author{
Michael P. Schlaile ${ }^{1,2}(-) \cdot$ Sophie Urmetzer ${ }^{1} \cdot$ Marcus B. Ehrenberger $^{3} \cdot$ Joe Brewer $^{2}$
}

Received: 7 October 2019 / Accepted: 3 August 2020 / Published online: 13 August 2020

(c) The Author(s) 2020

\begin{abstract}
In this paper, we explore the notion of systems entrepreneurship in the context of innovation systems (IS) dedicated to transformations towards sustainability. To this end, our paper draws primarily but not exclusively on the leverage points concept, which was originally proposed by Donella $\mathrm{H}$. Meadows and recently refined by sustainability scientists. More precisely, we flesh out four general propositions about the systems entrepreneurial process that serve as a starting point for illuminating how systems entrepreneurs can intervene at deep leverage points to introduce a dedication to sustainability in IS. The paper touches the important issues of directionality, formal institutions, as well as information flows and network structure that have received insufficient attention from researchers, policymakers, and practitioners aiming at transformations towards sustainability (e.g., funders and other support organizations). Taken as a whole, the paper serves as a conceptual basis for further theoretical and empirical work on systems entrepreneurs and dedicated IS. It should be read as a reminder that the fundamentally uncertain processes of systemic change call for collaborative efforts that transcend mental and organizational boundaries.
\end{abstract}

Keywords Systems entrepreneurship · Innovation systems $\cdot$ Dedicated innovation systems $\cdot$ Leverage points $\cdot$ Sustainability transitions $\cdot$ Transformative innovation

\section{Introduction}

Researchers and practitioners increasingly acknowledge that the global sustainability challenges such as climate change, ecological degradation, waste, or poverty are interconnected issues that must be explored and addressed from systemic perspectives. Put differently, many of these challenges cannot be tackled by thinking in terms of reductionist

Handled by Julia Leventon, Leuphana University, Faculty of Sustainability Scharnhorststr, Lueneburg, Germany.

Michael P. Schlaile

schlaile@uni-hohenheim.de

1 Department of Innovation Economics, University of Hohenheim, Wollgrasweg 23, 70599 Stuttgart, Germany

2 Center for Applied Cultural Evolution, 1776 Millrace Drive, Eugene, OR 97403, USA

3 KPMG AG Wirtschaftsprüfungsgesellschaft, Internal Audit Sustainability Services, Theodor-Heuss-Straße 5, 70174 Stuttgart, Germany cause-effect relationships (Senge 2006; Stroh 2015), since they are so-called wicked or persistent problems (Rittel and Webber 1973; Rotmans and Loorbach 2009) that are rooted in complex relationships between societal, economic, and environmental processes. Therefore, attempts at solving these problems without a proper systemic understanding can have unintended and non-linear effects, potentially making the problems even worse (Forrester 1971). Hence, systems thinking and notions of systemic change have recently gained increasing momentum in the social sector among philanthropists, not-for-profit organizations, funders, and foundations (e.g., Abercrombie et al. 2015; Hall and Schleicher 2017; Milligan et al. 2017; Mühlenbein 2018; Patton 2016; Stroh 2015). The question which actors are central for fundamentally changing the way humanity is doing business increasingly becomes one of the most important ones for both researchers and practitioners interested in remedying our world's sustainability challenges (Farla et al. 2012). This rising awareness of systemic issues and the complexity of societal, environmental, and economic problems also appears to have brought forth a new notion 
of social entrepreneurship, so-called "systems entrepreneurship" (Balfour 2017a, b; Milligan and Schwab 2017; Vexler 2017; Westley 2013). While systemic change has long been a central theme in the (social) entrepreneurship literature (e.g., see Newey 2018), the more recent shift from a focus on capable individuals to the recognition of social change as a complex issue involving collaborative efforts by multiple actors is not only justified but actually commendable considering the systemic root causes of many societal problems (e.g., Goldstein et al. 2009). New terminological and conceptual issues arise through this shift in focus, though, creating the potential for misunderstanding and detachment between academics and practitioners as well as different academic communities: While social entrepreneurship remains the term of choice for many academics, others have promoted sustainable entrepreneurship as an overarching concept (e.g., Schaltegger and Wagner 2011; Thompson et al. 2011), still others have advanced the notion of transformative or transformational entrepreneurship (e.g., Burch et al. 2016; Ratten and Jones 2019). Moreover, the literature on institutional entrepreneurship has long focused on how actors can contribute to changing institutions (e.g., Battilana et al. 2009; Westley et al. 2013), undoubtedly a central aspect of systemic social change.

Yet another school of thought, the literature on innovation systems (e.g., see Rakas and Hain 2019), has advanced the understanding of innovation and entrepreneurship in their systemic context, that is, as evolutionary phenomena involving interconnections and interactions between a diverse set of actors and institutions. Additionally, sustainability scientists have proposed to take up the concept of so-called "leverage points" as places to intervene in systems (originally suggested by Meadows 1999, 2008) to facilitate systemic changes towards sustainability (Abson et al. 2017; Dorninger et al. 2020; Fischer and Riechers 2019).

Given this broad literature and the urgency of many systemic problems that require transitions to sustainable development on multiple levels (e.g., Schlaile and Urmetzer 2019), a conceptualization of systems entrepreneurs is called for that aims at synthesizing this scattered knowledge instead of simply pouring new wine into old bottles. Hence, the guiding research question of this conceptual paper is: How and at which leverage points can entrepreneurs intervene to facilitate systems change by introducing a dedication to sustainability into innovation systems?

Following Pyka (2017) and Schlaile et al. (2017), the introduction of dedicated efforts to achieve sustainability in innovation systems is considered to be the desired systems change in the context of this paper (see also Chaminade 2020; Hekkert et al. 2020). Accordingly, any entrepreneurial activity involved in the process of introducing such dedicated effort can be understood in terms of systems entrepreneurship. It is, therefore, necessary to first clarify in the following section that we focus on (dedicated) innovation systems in our investigation. Departing from there, we detail what can qualify as innovation systems change, where in the innovation system these changes are expected to take place, what role systems entrepreneurs can play, and at which points of intervention (i.e., leverage points) they will be able to effect the desired change. In the subsequent section, we elaborate four general propositions connected to the systems entrepreneurial process. Based thereon, selected potential processes of systems entrepreneurship in innovation systems along different leverage points are sketched. The contribution of the paper to the conceptualization of systems entrepreneurship is specified and conclusions are drawn in the final section.

\section{Systems-what systems?}

Definitions of systems abound, perhaps among the broadest ones being "anything that is not chaos ... [or, alternatively,] any structure that exhibits order and pattern" (Boulding $1985, \mathrm{p} 9)$. In the context of this paper, we follow the more functional understanding of systems that was proposed by Meadows (2008): "A system is an interconnected set of elements that is coherently organized in a way that achieves something. ... [Hence,] a system must consist of three kinds of things: elements, interconnections, and a function or purpose" (p 11, emphasis removed). ${ }^{1}$ In the context of systemic change towards economically, socially, and environmentally sustainable systems that are better suited to tackle global challenges (e.g., as also targeted by the United Nations' Sustainable Development Goals), several relevant systems concepts have been developed (for reviews, see Schlaile and Urmetzer 2019; Urmetzer and Pyka 2019).

In this paper, we will primarily draw upon the framework of innovation systems (henceforth IS) and its quite recent variant called dedicated IS (Pyka 2017; Schlaile et al. 2017; Urmetzer et al. 2018; Urmetzer and Pyka 2019). The literature on IS supports the notion that the transformative potential of entrepreneurship does not simply arise from the genius of apt individuals or organizations (so-called "heropreneurs"). Instead, innovation and entrepreneurial activity are always embedded in and dependent on the institutional conditions such as culture (e.g., Edquist and Johnson 1997; Schlaile and Ehrenberger 2016) and actor configurations in the respective IS (Radosevic 2010), which some authors in the entrepreneurship community have reframed as "systems

\footnotetext{
1 Please note that, as also Kieft et al. (2020) caution, there are different terms for "elements" in the innovation systems and the system dynamics literature, including "components" but also "variables" and "concepts".
} 
of entrepreneurship" (e.g., Ács et al. 2014) or "entrepreneurial ecosystems" (e.g., Brown and Mason 2017; Kuckertz 2019; Roundy et al. 2018). Although there may be differences in meaning between the terms entrepreneurial ecosystems and IS, for the purpose of this paper we assume that they focus on quite similar things, namely, that innovation and entrepreneurship occur due to the interactions of interdependent actors, organizations, and institutions in a given context and that knowledge plays a central role (see also Stam and Spigel 2018, p 412, for a possible comparison). Arguably, for this paper, the similarities justify using IS as the overarching notion.

Since the concept emerged around the 1980s, IS have been further differentiated and refined (Rakas and Hain 2019). The "traditional" IS framework has a strong (often implicit) focus on technological innovations, competitiveness, and economic development, and we can draw upon a definition of a national IS as a general working definition:

An IS “... is an open, evolving and complex system that encompasses relationships within and between organizations, institutions and socio-economic structures which determine the rate and direction of innovation and competence-building emanating from processes of science-based and experience-based learning" (Lundvall et al. 2009, p 6).

In other words-and in accordance with the requirement of systemic approaches to complex change processes-the IS framework encompasses the interconnected set of actors and institutions contributing to the emergence of novelties (in the early literature mostly meaning new technologies). It allows researchers to consider the entire systemic environment of innovation, whereas prior inquiries into innovation were usually confined to the process leading to the creation and marketization of novelties and the outcomes of this process (in the sense of new products, new processes, new forms of organization, etc.). This conceptual shift from focusing on innovators to incorporating their systemic embedding has been discussed in the literature on IS at least since the development of the concept of national systems of innovation in the 1980s and is beyond the scope of our article. However, especially against the backdrop of the imminent global sustainability challenges that require innovative action, the "traditional" IS concept has been criticized and challenged (see Chaminade 2020; Schlaile et al. 2017; Urmetzer and Pyka 2019, for reviews).

To allow for the necessary transformations beyond technological remedies, IS need to incorporate a system-wide dedication to the continuity, resilience, and regeneration of social and ecological systems, inter- and intra-generational justice, quality of life, or generally sustainability. Such dedicated innovation systems (DIS) "explicitly go beyond technological innovation and economic growth and allow for paradigmatic change towards sustainability: They are 'dedicated' to foster the joint search for transformative innovations" (Pyka 2017, p 3). Here, we adopt the notion of "transformative innovation" (e.g., Steward, 2008; Loorbach et al. 2020), which goes beyond profound novelty in terms of products, processes, or practices:

"Transformative innovation is about radical change of a more generic kind. It is about the implementation of paradigm-breaking, system-wide novelty ... [that] crosses traditional sectoral boundaries and redraws existing social and economic arrangements" (Steward, 2008, p 15).

Before we can sketch potential processes of IS change, a contrasting juxtaposition of the status quo (IS) and the IS framework that aims at "more sustainable" outcomes (DIS) is necessary. The differences become apparent by defining the constituents for each system, namely, the elements, the interconnections, and the function or purpose (Meadows 2008). In the context of IS and DIS, elements may be organizations such as firms or universities, government agencies, and other social groups that are themselves sub-systems constituted by elements, interconnections, and functions or purposes. The IS's interconnections include all relations and interactions that connect the elements (e.g., financial flows, legal and policy links, scientific and business cooperation, and the communication of knowledge). According to Luhmann (1995), the interconnections or relations among the elements of a system are conditioned by so-called "constraints", meaning that they are subject to certain regulations which adds another layer to the level of interconnections. Finally, identifying functions or purpose is probably the hardest part of a system definition, and Meadows (2008) takes a quite practical approach by stating that functions and purposes are "deduced from behavior, not from rhetoric or stated goals" ( $p$ 14).

The difficulty of identifying systems' functions is also apparent in the literature on IS. Various functions have been proposed, including the explicit statement by Edquist (2005) that an IS's “main function ... is to pursue innovation processes" ( $p$ 182, italics in original). Another quite prominent list of functions was developed in the technological innovation systems (TIS) literature (Bergek et al. 2008; Hekkert et al. 2007). Given that DIS encompass many different levels, adopting any given list of functions would be insufficient, whereas the identification of an exhaustive set of DIS functions is beyond the scope of this paper and shall be regarded as an avenue for future research. On a quite general level, however, one may state that DIS differ from the conventional conceptualization of IS in that their main function is the pursuit of transformative innovation processes (in terms of paradigm-breaking, system-wide innovation; Steward 2008). Transformative innovation thus requires continuously re-thinking unsustainable-but hitherto 
unchallenged-trajectories. Consequently, it is important to note that both the conventional and the dedicated framework emphasize knowledge as an important functional element of IS. However, by taking up findings and concepts from sustainability science, in the DIS framework, the understanding and role of knowledge is broader, as conceptualized in terms of "dedicated knowledge" by Urmetzer et al. (2018). Table 1 sketches selected differences between the conventional IS and the DIS concept.

\section{Systems change and places for entrepreneurs to intervene in innovation systems}

Change theorists offer various perspectives on the motivation, the protagonists, the requirements, and the degree of systems change. Generally, intentional changes in systems become necessary when there is a discrepancy or mismatch between the desired and the actual system performance (Foster-Fishman et al. 2007). In earlier conceptualizations of system renewal, for example, in terms of "systemic innovation" as framed by Mulgan and Leadbeater (2013), the nature of the discrepancy addressed remains rather vague in the sense that innovation is meant to change the system "for the better" (Mulgan and Leadbeater 2013, p 4). By contrast, the proponents of DIS explicitly aim to overcome the incongruity of IS's normative orientation towards economic growth and technological solutions against the backdrop of urgent and global sustainability challenges (Schlaile et al. 2017).

In the context of this paper, the mismatch of IS calls for a systemic change in the sense of a transformation from IS to DIS. Following from the juxtaposition of systems' constituents (Table 1), this systems change corresponds to the alteration of either (i) the configuration of elements (e.g., actors including their capabilities and their aspirations), or (ii) of the types and patterns of systemic interconnections (e.g., including network structures and conditioning constraints such as formal rules or cultural values), or (iii) of the purpose of the IS (e.g., the system's emergent directionality) towards modes promoting transformative innovations. However, a fundamental shift or transformation to DIS can only be regarded as achieved once the level of function or purpose (iii) has been transformed. Yet, we acknowledge the possibility that a change in (i) and/or (ii) effectuates a change in (iii), thereby indirectly leading to a transformation to DIS.

But how can entrepreneurs become active in this transformation, thereby qualifying as systems entrepreneurs? At this point, we follow Hekkert et al. (2007), who define entrepreneurs as those actors of an IS that "turn the potential of new knowledge, networks, and markets into concrete actions to generate—and take advantage of-new business opportunities" (p 421). In our understanding, IS actors qualify as entrepreneurs if they (i) use new knowledge to (ii) generate and exploit new business opportunities, while (iii) co-creating the IS around them. The latter moves into focus, where systems changing entrepreneurial processes are to be explored (Westley 2013).

Balfour (2017b) defines the systems entrepreneur as "a person or organization that facilitates a change to an entire ecosystem [or IS, n.b.] by addressing and incorporating all the components and actors required to move the needle on a particular social issue." According to Milligan et al. (2017, p 10), "systems entrepreneurs are moving beyond delivering solutions and instead are focusing on the architecture of the system itself." We can thus regard systems entrepreneurship as a systemic process leading to change in one or more of the three systems' constituents-elements, interconnections, and functions or purpose (see above). Systems entrepreneurs are thus expected to have a say in the alteration on all three levels as a "catalytic force that creates momentum among all the other actors" (Balfour 2017b). ${ }^{2}$

Before we fathom the conceptual details of the process of systems entrepreneurship in the following section, it is essential to consider the potential points (and subsystems) in an IS, where systemic actors are most likely to induce the intended change. On a general level, these points have been described by Meadows (1999) as leverage points (see also Abson et al. 2017; Dorninger et al. 2020). Due to the interconnectedness and complexity of systems, it is regarded as extremely difficult to design interventions such that they change the system in a desired direction. The leverage points framework provides a ranking of potential points of intervention in systems along a gradient of increasing effectiveness but also increasing difficulty. It ranges from interventions that are relatively easy to implement but usually not very effective in changing the system (shallow leverage points) to, at the other end, interventions that are highly effective in changing the system but very hard to implement (deep leverage points). As, for example, Senge notes, one of the central problems making interventions at these deep leverage points so difficult "is that high-leverage changes are usually highly nonobvious to most participants in the system" (Senge 2006, p 64, italics in original).

Kieft et al. (2020) have recently applied the leverage points ranking to TIS, thereby revealing relevant synergies between the concepts of leverage points and IS. We adjust their TIS framework and terminology for our DIS context to explore entrepreneurial activity at the following three deep leverage points: ${ }^{3}$

\footnotetext{
2 This does not imply, however, that only networking activities are important in the context of systems entrepreneurship.

3 As TIS focus on analyzing the innovation and diffusion processes around emerging technologies (see also Kukk et al., 2015, for a brief review), whereas DIS focus on transformative innovations and integrating a dedication to sustainability transitions (Schlaile et al., 2017), we could not simply follow the terminology used by Kieft et al. (2020) in every respect.
} 


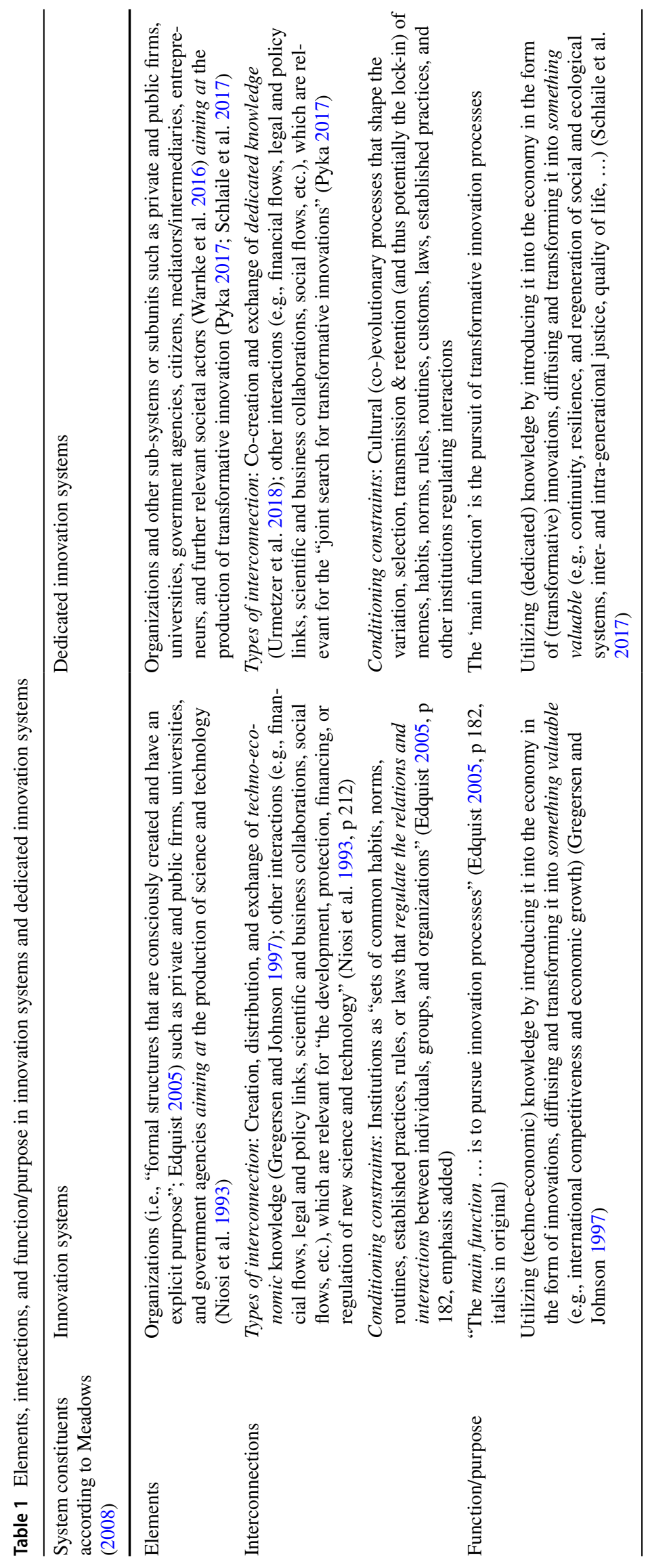


1. Directionality, which relates to Meadows' leverage points of "goals" and "paradigms" and describes a system's "intent" (Abson et al. 2017): Collective direction of actor goals and informal institutions (paradigms, worldviews, norms, values) that shape the direction of transformative innovation (loosely following Kieft et al. 2020).

2. Formal institutions, which relate to Meadows' leverage points of "rules" and have some overlaps with "selforganization" determining the institutional "design" (Abson et al. 2017) of an IS: Formal institutions such as codified rules of the game (e.g., formalized in laws, procedures, standards, or codes of conduct) as well as the room they provide for self-organization and change (Kieft et al. 2020).

3. Information flows and network structure, which relate to Meadows' leverage points of the "structure of information flows", also have some overlaps with "self-organization" and the setup or "design" (Abson et al. 2017) of the IS: Structural elements of actors, the knowledge infrastructure, and the physical infrastructure that influences knowledge and information flows (e.g., Kieft et al. 2020); also known as "innovation network" (e.g., Ahrweiler and Keane 2013).

Our analysis of entrepreneurial processes will be restricted to those three deep leverage points for the following reason: Systems-changing interventions or entrepreneurial actions that contribute to transforming IS to DIS will hardly be potent at shallow leverage points (cf. Abson et al. 2017). On the contrary, systems entrepreneurs qualify for this term only if they effect changes to the entire IS. ${ }^{4}$

\footnotetext{
${ }^{4}$ Note that, in this regard, Klein Woolthuis (2010) has offered the distinction between system following entrepreneurs and system building entrepreneurs (see also the related discussions in Farla et al. 2012; Kukk et al. 2015). Entrepreneurship may well be conceivable as following existing systems' rules and structures (system following entrepreneurs) and still enhance the sustainability of the entire system. This could be achieved, for instance, by increasing the production of sustainable alternatives to unsustainable products or improving the environmental performance of certain production processes-interventions at rather shallow leverage points. Systems entrepreneurs, by contrast, can arguably be understood as system building entrepreneurs in the sense that they do not perpetuate existing networks and institutions; they challenge existing power relations and actively create new networks (Klein Woolthuis 2010)_interventions at deep leverage points.
}

\section{Characteristics of system-changing entrepreneurial activity}

\section{Acting under uncertainty}

The main challenge for systems entrepreneurs (and for scholars describing the process of systems entrepreneurship, for that matter) consists in choosing which actions are appropriate for the goal of changing the IS. Generally, it can be argued that IS are characterized by a high degree of uncertainty. In situations under true uncertainty, we are dealing with an unmeasurable type of not even knowing what the possible outcomes are, combined with the absence of repeatability due to the uniqueness of context for each episode of innovative activity. In the context of systems change, objective calculations of probabilities of occurrence are largely impossible, because no experience values exist for unprecedented and unparalleled interventions. Consequently, systems entrepreneurs can strive to change an IS by certain means, but they cannot-or only to a very limited extentanticipate the ramifications of their systemic interventions. Accordingly, we can formulate

Proposition 1 Systems entrepreneurs are confronted with decision situations under high uncertainty.

\section{Subjective opportunities}

A key element of any entrepreneurial process is the entrepreneurial opportunity (e.g., Ehrenberger 2017; Hansen et al. 2011; Kuckertz and Wagner 2010; Short et al. 2010). The concept of entrepreneurial opportunities will help us to identify potential leverage points for systems entrepreneurs. There is a long-running debate among entrepreneurship scholars whether an entrepreneurial opportunity objectively exists waiting to be discovered and exploited by an entrepreneur (i.e., the so-called discovery view), or whether the creation of an opportunity that has not existed before (i.e., the so-called creation view) is actually part of the entrepreneurial process (e.g., Alvarez et al. 2013). To the extent that systems change implies a context of entrepreneurial action under uncertainty (cf. Proposition 1), we may expect better insights into the systems entrepreneurial process from taking up the creation view. The creation and exploitation of a systems entrepreneurial opportunity consequently represents a possibility for entrepreneurs to create a new IS or afford changes in an existing one. In accordance with the creation view, systems entrepreneurial opportunities are, therefore, subjective phenomena that are not independent from the entrepreneur's worldviews and behaviors. As also Schlaile and Ehrenberger (2016) suggest, culturally evolved mental 
representations may determine the entrepreneurs' heuristics and information filters, thereby potentially delimiting the possibility space of opportunities by means of cultural schemata and culture-based creativity. This leads us to

Proposition 2 A systems entrepreneurial opportunity can be understood as the subjective possibility to afford a new and system-changing solution to a systemic problem.

\section{Open-ended co-creation}

The systems entrepreneurial process can thus be understood in terms of a cooperative and co-creative process that is undirected in the beginning inasmuch as the vision or idea of the potential opportunity is rather vague - or at least not concretely fixed. Yet, this initial openness is essential, because cooperating stakeholders contribute to the enterprise not only with their own resources and capabilities but also with their diverse worldviews, goals, and value systems. These "inputs" give a direction to the co-creation of the systems entrepreneurial opportunity in a way that cannot be anticipated by the systems entrepreneur at the beginning of the entrepreneurial process. Hence, the goal of the whole cocreative and cooperative endeavor is up for negotiation right from the beginning, and the final outcome will emerge from a "series of transformations" (Sarasvathy 2008, p 112) by interacting agents. In other words, systems entrepreneurial opportunities are co-created in collaboration with the other actors within an existing or nascent IS. These considerations allow us to formulate

Proposition 3 Systems entrepreneurial opportunities are cocreated and shaped by the resources, capabilities, worldviews, goals, and value systems of the stakeholders negotiating and enacting them.

\section{Seeds of change}

As we know from the literature on diffusion of innovations (Rogers 2003) and tipping points (Lamberson and Page 2012), novelties need to attract a certain number of imitators or adopters - a critical mass that must be reached-in order for the innovation to make a difference (e.g., in the sense of "going viral" or being an effective leverage point). This insight can also be applied to systems entrepreneurs: An initial agreement with other stakeholders must initiate a new chain of commitments that attracts the critical mass to advance the dedication to systemic transformations towards sustainability.
Proposition 4: Systems entrepreneurs cannot change the function or purpose of an IS on their own; they need to attract a critical mass of cooperating stakeholders to create a chain of commitments that reaches a tipping point.

The above propositions describe the conceptual basis upon which we will build our considerations of the entrepreneurial interventions at the different deep leverage points in the following section.

\section{Potential avenues of systems entrepreneurship at deep leverage points}

\section{Leverage point 1: directionality}

As mentioned above, the directionality lever for effecting change in an IS refers to transforming (the collective direction of) actor goals and informal institutions such as paradigms, worldviews, norms, and values that shape the direction of transformative innovation processes (loosely following Kieft et al. 2020).

An opportunity co-created by a systems entrepreneur at this lever acts upon the system's performance by influencing the collaborators' goals and paradigms and thus potentially seeding change in the emergent purpose of the whole IS. At the leverage point of directionality, systems entrepreneurs thus have the possibility to effect a change on all three system constituents: Elements (especially their aims), interconnections, and purpose/function.

At the level of system elements, a systems entrepreneur must seek to identify and convene relevant stakeholders and actively strive to build consensus among them. These relevant stakeholders comprise potential customers, suppliers, or competitors as well as regulatory and civil society actors (see also Warnke et al. 2016). The systems entrepreneur takes on the role of an "influence agent" (Wood and McKinley 2010, p 79) or "honest broker" (Balfour 2017b; Milligan and Schwab 2017; Vexler 2017; Westley 2013) who aims at co-creating an opportunity and aligning the differing paradigms (e.g., mindsets and worldviews influencing the goals) of participating stakeholders.

It is important to keep in mind that the systems entrepreneurs themselves as well as all stakeholders contribute to the opportunity creation process with their individual worldviews, paradigms, and values (cf. Propositions 2 and 3 ) that will also be subject to change (e.g., Schlaile and Ehrenberger 2016). Therefore, and due to the inherent uncertainty of systems entrepreneurial processes (cf. Proposition 1), the change of goals and aims of the IS's actors is a nonpredictive and non-teleological (i.e., open-ended) venture (Sarasvathy 2008). This (systems) entrepreneurial venture is arguably heavily dependent on "a network of stakeholders 
engaged in an ongoing process of (re)negotiating the design of innovations" (Dew and Sarasvathy 2007, p 275, emphasis removed) or systemic interventions, for that matter.

At the level of interconnections within the IS, the entrepreneur may seek to challenge the informal conditioning constraints of the innovation networks, for example, by crossing the mental boundaries of disciplines and social classes and by challenging established rules of collaboration (e.g., Bornstein 2007), or by introducing new formats of organization and cooperation (e.g., Battilana and Lee 2014).

But while a change in numbers, aims, and cooperation modes of stakeholders certainly holds the potential of contributing to a change of collective goals, we cannot expect these processes to reach the critical mass or scale inducing the change in function/purpose (cf. Proposition 4) of the entire IS by themselves. Especially due to the potentially conflicting goals and worldviews of stakeholders, systems entrepreneurs walk a fine line between increasing scale and potential dilution of goals.

A powerful tool for systems entrepreneurs at the directionality lever can be storytelling: By recognizing that language is central to sensemaking and meaning (e.g., Gutknecht 2017), we can see how stories and narratives may influence the paradigms of a system (e.g., Ollove and Lteif 2017; Stroh 2015, Chap. 3). For example, a large body of literature exists in the domain of cognitive linguistics about the use of meta-cognitive tools for conceptualizing identities and categories in a specific social context (e.g., Lakoff 2010; Lakoff and Johnson 1980). Typically, this kind of research focuses on the framing of media in communications and marketing. A systems entrepreneur may alter the composition of stories in a manner that opens up new ways to interact within a social setting, including how the various stakeholders construct mental categories and perceive the sustainability issues involved (Crompton et al. 2010; Waddock 2016). Strategic framing efforts aim at challenging the foundational concepts that constituted the "common sense" for previous activities. This can be done by introducing new metaphors to show how ill-conceived notions have hindered progress in the past.

\section{Leverage point 2: formal institutions}

The leverage point of so-called formal institutions includes codified rules of the game that are, for example, formalized in laws, procedures, standards, or codes of conduct. These formal institutions also define boundaries for a system's self-organization and change processes (e.g., Edquist and Johnson 1997; Kieft et al. 2020). Although the design or enactment of formal institutions has frequently been the task of governments, the role of the state in providing top-down regulation is no longer self-evident especially when it comes to global sustainability issues calling for transformative innovations (Schlaile et al. 2017). Moreover, as Edquist and Johnson (1997, p 57) caution, "formal institutions cannot be designed without taking the evolution of informal institutions into account." This means, for example, that the codification of rules, which leads to their formal institutionalization, heavily relies on the (cultural) evolution of the worldviews at the paradigm level and the actors involved in legislation, for example. From a systemic perspective, therefore, formal institutions are conditioning constraints (e.g., in the sense of Luhmann 1995) that are (evolutionarily) stabilized by being codified.

Despite their resilience, however, formal institutions are anthropogenic and can be changed, affecting primarily (but not exclusively) the level of interconnections. Systems entrepreneurs can play a role in this change, for example, by engaging with and lobbying the relevant governmental agencies (Milligan et al. 2017) — especially when having acquired a sufficient critical mass of collaborators to be heard (cf. Proposition 4). Moreover, at a potentially scalable individual or organizational level, systems entrepreneurs can implement new contractual relations, private standards, and codes of conduct with cooperating stakeholders. In this regard, however, it is important to remember from institutional economics that contracts are usually incomplete (Williamson 1985), which is especially the case in the context of systems entrepreneurship due to it being characterized by a high degree of uncertainty (cf. Proposition 1). Now the additional difficulty arises that incomplete contracts are generally prone to exploitation by opportunistic agents (Williamson 1985). Despite this rather obvious obstacle of opportunism (which can be expected given the vested interests of incumbent system actors), systems entrepreneurship actually requires incomplete contracts to retain the transformative potential of the stakeholder network, which can continually re-negotiate its formal institutions based on collective learning and adaptation.

\section{Leverage point 3: information flows and network structure}

The leverage point of information flows and network structure defines the point of intervention for structural elements of actors, the knowledge infrastructure, and the physical infrastructure that influences knowledge and information flows (e.g., cf. Kieft et al. 2020). In the context of IS, we can also refer to these structural elements and connections in terms of innovation networks (e.g., Ahrweiler and Keane 2013). Consequently, this leverage point primarily affects the levels of elements and interconnections of the IS.

Following from the notion that the systems entrepreneurial process is undirected at the beginning (Proposition 3), the selection and inclusion of stakeholders cannot be understood as a genuinely goal-directed process on behalf of the systems 
Fig. 1 Potential places for systems entrepreneurs to intervene in innovation systems at different levels of change (bold) and possible entrepreneurial actions (italics)

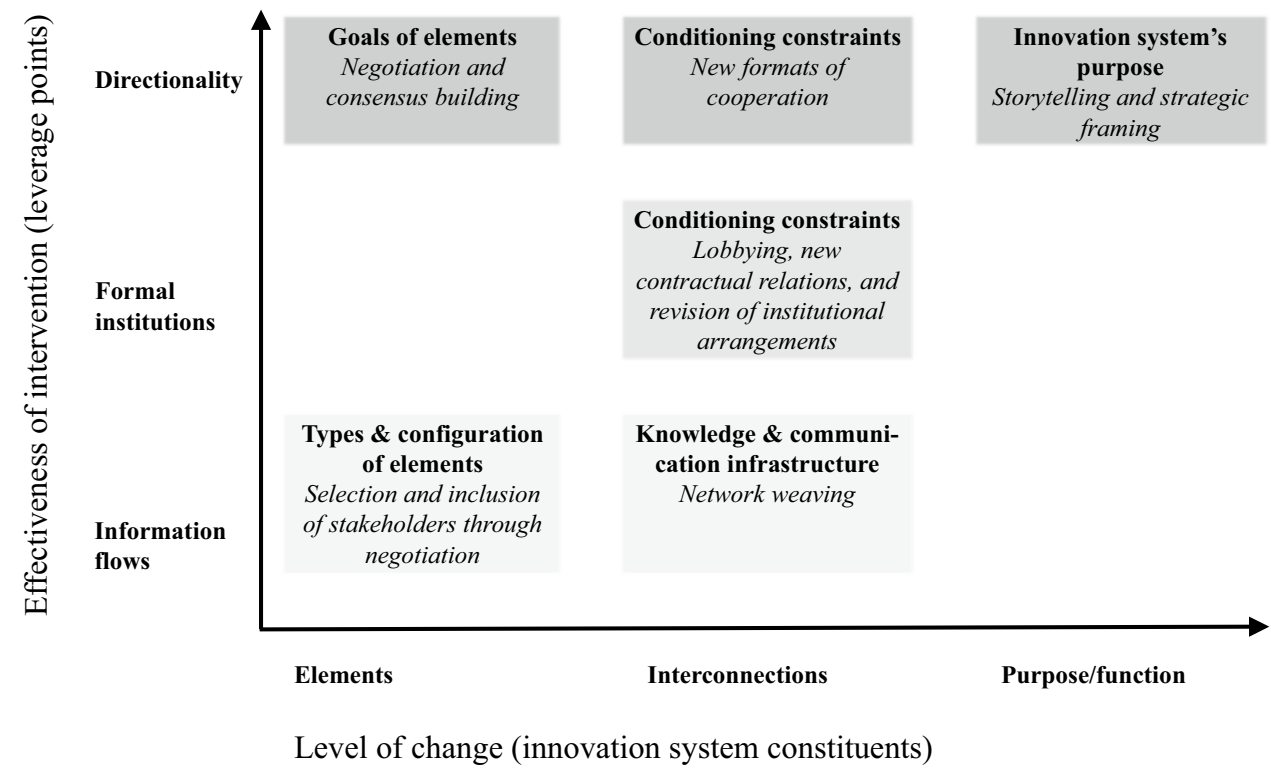

entrepreneur. In the context of knowledge and information flows, this also means that there is no "optimal" innovation network structure the systems entrepreneur can aim at because the notion and understanding of knowledge goes beyond the traditional understanding of (economically relevant) knowledge in IS (Urmetzer et al. 2018). For the systems entrepreneur, this simultaneously implies that including more stakeholders can help to absorb some of the detrimental (economic) consequences associated with uncertainty. Nevertheless, there will be a trade-off between aiming to include many actors from diverse knowledge backgrounds, which may also entail the danger of diluting the goals, and including those stakeholders that hold the network position and power to influence the direction of knowledge and information flows (e.g., Urmetzer et al. 2018; see also Blok 2018, on a similar argument).

Generally, at this leverage point, the entrepreneur can engage in so-called "network weaving" that alters the connectivity among diverse agents in the IS (e.g., Holley 2013). For this network weaving by the systems entrepreneur, one can take up the literature on institutional entrepreneurship, which distinguishes the three central concepts of bonding, bridging, and linking (Westley et al. 2013): Bonding refers to connecting with similar others (e.g., among local organizations), bridging means bringing together similar and/or different stakeholder groups to gain support and create momentum, and linking denotes communication and engagement with key stakeholders in different sectors and across scales.

\section{Summary: leverage points and system constituents at a glance}

In summary, we can ween from these approaches the insights that (a) system entrepreneurs can alter the type and structure of elements, interconnections, and-indirectly-the purpose or function of a given IS; and (b) analytic tools exist to help them build up knowledge as they go that improves their efficacy in practice. For an overview, the loci of potential change in the IS are illustrated in a matrix plotting the IS's constituents against the three leverage points discussed (Fig. 1).

The boxes represent the parameters subject to (potential) systems entrepreneurial change (bold box labels) and contain proposed actions to effect the change (annotations in italics). These possible actions that are introduced and explored above (this section) clearly represent a selective and non-exhaustive assemblage of approaches and concepts that might be taken into consideration by entrepreneurs who seek to expand their knowledge towards system-changing capabilities. By no means shall they be read as a general blueprint for systems entrepreneurs. We must stress that both the selectivity and the limited practical applicability of the suggested approaches require further reflection and experimentation. From case to case, further elaboration will have to be accompanied by careful consideration of the respective cultural, geographical, political, and economic context of the system to be changed.

Furthermore, we must caution against the reduction of complexity of the notion of leverage points. The clearly delineated boxes and arrows shown in the graph and-to a lesser extent-the deliberations above may suggest that 
there exists a straightforward distinction between the various leverage points. However, this does not reflect reality: Leverage points must be considered to be interdependent, and interventions at a certain point may significantly affect (the need for) interventions at other points (Abson et al. 2017). Likewise, the system constituents depend on each other and interact (Meadows 2008), which becomes apparent when we think about how elements form the structure of interconnections or how knowledge flows determine the function/purpose of an IS. And, since there are "no cheap tickets to mastery" (Meadows 1999, p 19), it goes without saying that the efforts the systems entrepreneur needs to put into the different interventions must increase along both of the interconnected gradients, from lower to higher system levels ( $X$ axis) as well as from lower to higher degrees of effectiveness ( $Y$ axis).

\section{Conclusion and outlook}

This paper has aimed at exploring how, and at which leverage points, entrepreneurs can intervene to facilitate systems change by introducing a dedication to sustainability into IS. Although the paper is just a first step in the direction of conceptualizing systems entrepreneurship, we contribute to the interdisciplinary literature on transformations to sustainability and IS by showing how the leverage points concept can be applied to understand and improve system-changing entrepreneurial activities. The four propositions developed above shed light on the nature of the systems entrepreneurial process as characterized by uncertainty, subjective opportunities, co-creation of opportunities, and the dependence on a critical mass of stakeholders to reach a tipping point. Our discussion of entrepreneurial interventions at the three deep leverage points of directionality, formal institutions, and information flows and network structure reveals several insights which allows us to formulate relevant implications for systems entrepreneurs, their support organizations (e.g., funders, facilitators), and future research into the phenomenon of systems entrepreneurship.

Before we conclude the paper with these implications, a general caveat has to be acknowledged (in addition to the limitations we already mention in the respective sections above): By basing our understanding of an entrepreneur on Hekkert et al. (2007), we have implied that creating and exploiting business opportunities is also part of the entrepreneurial process. In the context of sustainability, which involves a social, an economic, and an environmental dimension, this may create the impression that we are implicitly following a "win-win paradigm". However, this is not the case. By taking up the concepts of leverage points and DIS, we acknowledge the systemic nature of sustainability issues and that there can also be feedbacks and trade-offs between solving social and environmental problems and having a viable business model. In the same vein, Blok (2018) has recently illuminated the inherent paradoxes and trade-offs between sustainability and entrepreneurial activity. We thus argue in favor of conceptual clarity, which means that systems entrepreneurs in our sense should be distinguished from a range of so-called "innovation brokers" (e.g., Klerkx and Leeuwis 2009) or "transition intermediaries" involved in systemic changes towards sustainability (e.g., Kivimaa et al., 2019a, 2019b $)^{5}$ and from other, more profit-driven entrepreneurs. For example, if the motivation for systems entrepreneurs is to change an IS, they may continue to invest their time and resources in projects with a high degree of positive externalities, while for other entrepreneurs this setting might provide little incentive for creating value (see also Kuckertz et al. 2019, for a related discussion on value creation in ecological startups).

The implications of our discussions are manifold, and the following list should thus be seen as non-exhaustive. The first implication that can be derived from the openendedness and uncertainty of the systems entrepreneurial process is that systems entrepreneurs should aim at creating a team that consists of an adequate number of generalists at the beginning of the process, simply because the expertise required for the particular systemic intervention will only be revealed over time. In other words, the new means-end relationship of the systems entrepreneurial intervention is ex ante unknown for the systems entrepreneur: While a vision of a new means-end framework may be present with more traditional entrepreneurial opportunities (Shane 2003)even sustainable ones (Schaltegger and Wagner 2011; York and Venkataraman 2010), for systems entrepreneurs the means and ends of a systemic intervention are not clearly defined. More likely, they will change and become more palpable only over time-even if the intention to change the IS exists in the beginning of the entrepreneurial process. Moreover, as we know from systems theory, goals of individual actors may differ greatly from the function(s) achieved by the system in the end (see also Forrester 1971; Stroh 2015). Hence, a team with a high degree of flexibility and transdisciplinary knowledge may be more appropriate at the outset, whereas the recruiting of experts will become more important once the systems entrepreneurial opportunity becomes more palpable. In this regard, however, we want to caution against viewing systems entrepreneurship

\footnotetext{
${ }_{5}^{5}$ We are aware that some authors and funding agencies also include those individuals and organizations into the set of social entrepreneurs or systems entrepreneurs that solve societal / systemic problems but do not have a viable business model (e.g., because they depend solely on donations). However, we would rather consider these change agents as so-called transition intermediaries as conceptualized by Kivimaa et al. (2019a) and Kivimaa et al. (2019b).
} 
as generally consisting only of a collective or networking effort. Individual actions by entrepreneurs can indeed have an impact on changes in an IS (e.g., Kukk et al., 2015), and this may particularly hold for the directionality lever and for some of the more shallow leverage points not discussed in this article.

A second implication of uncertainty is that particularly systems entrepreneurs cannot draw on risk-based evaluation toolkits and other planning approaches to assessing opportunity costs or make decisions for or against exploiting particular opportunities. Instead, uncertainty requires the systems entrepreneur to use heuristics as well as adaptive, iterative, and experimental learning processes to reveal alternative pathways that are potentially least threatening to the systems entrepreneur's existence.

Third, since we are concerned with interventions that shape the evolution of entire IS, a systems entrepreneur might observe that differential cultural evolution leads to a variety of different initial conditions for systemic interventions. For example, in a given cultural setting there may be a strong emphasis on family relations (as is the case in clan-based societies) that makes collaboration difficult to scale upward. Another setting might have strong planning agencies as part of the municipal or regional governmentindicating that progress can only be made by building alliances across key individuals on various committees in the different agencies involved.

All these insights are also relevant to the support organizations (e.g. foundations, impact investors, funding agencies), especially those who already share worldviews, values, and goals with systems entrepreneurs working to transform IS. Truly systemic entrepreneurs will often struggle to find financial support early in the process, because they are operating within conditions of high uncertainty while continually re-negotiating contracts with prospective allies. Rather than seeing these features as weaknesses, the analysis presented here reveals them to be core features of truly systemic interventions. Thus, they offer new pathways for transformative innovation. Consequently, organizations striving to support systems entrepreneurship must welcome experimentation and uncertainty by shifting away from mere planning-based approaches.

Finally, this paper points to several promising directions for further research. First and foremost, our propositions should be tested by means of empirical studies, including case studies of successful systems entrepreneurs. In this regard, researchers interested in the qualitative and quantitative metrics for the evolution of the systems entrepreneur's stakeholder network can employ tools from network science to track the evolution of these connections across time.

A second promising avenue for further research could be a more differentiated analysis of possibilities for systems entrepreneurial interventions by new entrants (e.g., startups) as opposed to interventions by "intrapreneurs" (or so-called corporate entrepreneurs) within the sub-systems of incumbent organizations. In this context, it would be particularly interesting to investigate how a dedication to sustainability transitions could be introduced by economically viable enterprises (e.g., how and which new narratives are needed, who are the key drivers and opponents in extant organizations, etc.).

Since, in this paper, we have drawn upon the notion of entrepreneurial opportunities, a third interesting research question could be how the systems entrepreneurial process can be conceptualized without drawing on opportunities, given the fact that the explanatory value of the concept of entrepreneurial opportunities has recently been challenged (e.g., Foss and Klein 2018).

A fourth relevant direction for future research revolves around the issue of knowledge creation, diffusion, and transformation into something valuable by systems entrepreneurs and their stakeholder networks. Due to knowledge being an important input and output of transformative innovation processes, the question remains how "dedicated knowledge" necessary for systems entrepreneurs can be institutionalized, how a lock-in into "unsustainable" knowledge bases can be avoided or overcome, and which new modes of learning and education are required.

Another open issue remains in the area of leverage points for systems entrepreneurs. It would be worthwhile to examine the identified points for successful entrepreneurial intervention in more detail, possibly expanding their scope, and discovering how they influence each other positively or negatively while also incorporating the shallow leverage points. In this regard, special attention should also be paid to differences between systems entrepreneurial actions on a more individual level and the actions on a collective level that relate to or require participation from other system actors.

Essentially, in this paper, we have followed Meadows' (1999) invitation to think more broadly about the possible interventions to prompt systemic changes, albeit being aware that leverage points are not a "recipe" for success. Consequently, we provided a qualified starting point for more rigorous and well-founded analyses into systems entrepreneurial interventions.

Acknowledgements We have benefited from presenting earlier versions of this article at the Leverage Points 2019 international conference on sustainability research and transformation (6-8 February, 2019) in Lüneburg, Germany, and at the European Academy of Management (EURAM) conference (26-28 June, 2019) in Lisbon, Portugal. We are grateful for comments, questions, and suggestions from reviewers, discussants, and participants of both events. Moreover, we acknowledge that a large part of the inspiration for this paper came from the Social Innovation Summit 2018: Joint Vision. Collective Action. Better Future. (9-10 March, 2018) in Stuttgart, Germany. Presentations of and discussions with Louis Klein, Katherine Milligan, André Reichel, and Matthias Scheffelmeier as well as other attendees 
of the Social Innovation Summit were crucial for shaping the evolution of this article. Finally, we want to express our gratitude towards the two anonymous reviewers for this journal, who helped us to sharpen our contribution, and to the guest editors for inviting us to submit our paper to this special issue.

Funding Open Access funding provided by Projekt DEAL. Open Access funding provided by Projekt DEAL. This work has received no specific funding from public or private sources.

\section{Compliance with ethical standards}

Conflict of interest The authors declare that they have no competing interest.

Open Access This article is licensed under a Creative Commons Attribution 4.0 International License, which permits use, sharing, adaptation, distribution and reproduction in any medium or format, as long as you give appropriate credit to the original author(s) and the source, provide a link to the Creative Commons licence, and indicate if changes were made. The images or other third party material in this article are included in the article's Creative Commons licence, unless indicated otherwise in a credit line to the material. If material is not included in the article's Creative Commons licence and your intended use is not permitted by statutory regulation or exceeds the permitted use, you will need to obtain permission directly from the copyright holder. To view a copy of this licence, visit http://creativecommons.org/licenses/by/4.0/.

\section{References}

Abercrombie R, Harries E, Wharton R (2015) Systems change: a guide to what it is and how to do it. New Philanthropy Capital, London

Abson DJ, Fischer J, Leventon J, Newig J, Schomerus T, Vilsmaier $\mathrm{U}$, von Wehrden $\mathrm{H}$, Abernethy P, Ives CD, Jager NW, Lang DJ (2017) Leverage points for sustainability transformation. Ambio 46:30-39. https://doi.org/10.1007/s13280-016-0800-y

Ács ZJ, Autio E, Szerb L (2014) National Systems of Entrepreneurship: Measurement issues and policy implications. Res Policy 43:476-494. https://doi.org/10.1016/j.respol.2013.08.016

Ahrweiler P, Keane MT (2013) Innovation networks. Mind Soc 12:7390. https://doi.org/10.1007/s11299-013-0123-7

Alvarez SA, Barney JB, Anderson P (2013) Forming and exploiting opportunities: The implications of discovery and creation processes for entrepreneurial and organizational research. Organ Sci 24:301-317. https://doi.org/10.1287/orsc.1110.0727

Balfour D (2017a) Doing good great: An insider's guide to getting the most out of your philanthropic journey, Abridged edn. Geneva Global, Paoli

Balfour D (2017b) Want big social change? Find a systems entrepreneur. HuffPost, 01/10/2017: https://www.huffingtonpost.com/entry /want-big-social-change-find-a-systems-entrepreneur_us_58753 9e1e4b0a5e600a78f49. Accessed 5 June 2020

Battilana J, Leca B, Boxenbaum E (2009) How actors change institutions: Towards a theory of institutional entrepreneurship. Acad Manag Ann 3:65-107. https://doi.org/10.1080/19416520903053598

Battilana J, Lee M (2014) Advancing research on hybrid organizinginsights from the study of social enterprises. Acad Manag Ann 8:397-441. https://doi.org/10.1080/19416520.2014.893615

Bergek A, Jacobsson S, Carlsson B, Lindmark S, Rickne A (2008) Analyzing the functional dynamics of technological innovation systems: a scheme of analysis. Res Policy 37:407-429. https:// doi.org/10.1016/j.respol.2007.12.003
Blok V (2018) Information asymmetries and the paradox of sustainable business models: Towards an integrated theory of sustainable entrepreneurship. In: Moratis L, Melissen F, Idowu SO (eds) Sustainable business models: principles, promise, and practice. Springer, Cham, pp 203-225

Bornstein D (2007) How to change the world-social entrepreneurs and the power of new ideas. Oxford University Press, Oxford

Boulding KE (1985) The world as a total system. SAGE, Newbury Park

Brown R, Mason C (2017) Looking inside the spiky bits: a critical review and conceptualisation of entrepreneurial ecosystems. Small Bus Econ 49:11-30. https://doi.org/10.1007/s11187-017-9865-7

Burch S, Andrachuk M, Carey D, Frantzeskaki N, Schroeder H, Mischkowski N, Loorbach D (2016) Governing and accelerating transformative entrepreneurship: Exploring the potential for small business innovation on urban sustainability transitions. Curr Opin Environ Sustain 22:26-32. https://doi.org/10.1016/j.cosus t.2017.04.002

Chaminade C (2020) Innovation for what? Unpacking the role of innovation for weak and strong sustainability. J Sustain Res 2:4. https ://doi.org/10.20900/jsr20200007

Crompton T, Brewer J, Kasser T (2010) Values, framing, and the challenge of climate change. In: Rowley S, Phillips R (eds) From hot air to happy endings: How to inspire public support for a low carbon society. Green Alliance, London, pp 46-51

Dew N, Sarasvathy SD (2007) Innovations, stakeholders \& entrepreneurship. J Bus Ethics 74:267-283. https://doi.org/10.1007/s1055 1-006-9234-y

Dorninger C, Abson DJ, Apetrei CI, Derwort P, Ives CD, Klaniecki K, Lam DPM, Langsenlehner M, Riechers M, Spittler N, von Wehrden H (2020) Leverage points for sustainability transformation: a review on interventions in food and energy systems. Ecol Econ 171:106570. https://doi.org/10.1016/j.ecolecon.2019.10657 0

Edquist C, Johnson B (1997) Institutions and organizations in systems of innovation. In: Edquist C (ed) Systems of innovation: Technologies, institutions, and organizations. Pinter, London, pp 41-63

Edquist C (2005) Systems of innovation: perspectives and challenges. In: Fagerberg J, Mowery DC, Nelson RR (eds) The Oxford handbook of innovation. Oxford University Press, Oxford, pp 181-208

Ehrenberger M (2017) Corporate Social Entrepreneurship: Prozess und Form ökonomischer Organisation zur Kreation sozialunternehmerischer Opportunitäten. Metropolis, Marburg

Farla J, Markard J, Raven R, Coenen L (2012) Sustainability transitions in the making: A closer look at actors, strategies and resources. Technol Forecast Soc Chang 79:991-998. https://doi. org/10.1016/j.techfore.2012.02.001

Fischer J, Riechers M (2019) A leverage points perspective on sustainability. People Nat 1:115-120. https://doi.org/10.1002/pan3.13

Forrester JW (1971) Counterintuitive behavior of social systems. Theor Decis 2:109-140. https://doi.org/10.1007/BF00148991

Foss N, Klein P (2018) Entrepreneurial opportunities: who needs them? Acad Manag Perspect. https://doi.org/10.5465/amp.2017.0181

Foster-Fishman PG, Nowell B, Yang H (2007) Putting the system back into systems change: A framework for understanding and changing organizational and community systems. Am J Community Psychol 39:197-215. https://doi.org/10.1007/s10464-007-9109-0

Goldstein JA, Hazy JK, Silberstang J (2009) Complexity, systems thinking, and social entrepreneurship: A future of possibilities. In: Goldstein JA, Hazy JK, Silberstang J (eds) Complexity science and social entrepreneurship: Adding social value through systems thinking. ISCE Publ, Litchfiled Park, pp 111-133

Gregersen B, Johnson B (1997) Learning economies, innovation systems and european integration. Reg Stud 31:479-490. https://doi. org/10.1080/00343409750132270

Gutknecht D (2017) Meaning at work and its hidden language. Aviri, Austin 
Hall R, Schleicher A (2017) The Global Change Leaders' framework for change. The GCL: https://de.scribd.com/document/46240 4884/The-Global-Change-Leaders-FRAMEWORK-FORCHANGE-July-2017. Accessed 5 June 2020

Hansen DJ, Shrader R, Monllor J (2011) Defragmenting definitions of entrepreneurial opportunity*. J Small Bus Manag 49:283-304. https://doi.org/10.1111/j.1540-627X.2011.00325.x

Hekkert MP, Janssen MJ, Wesseling JH, Negro SO (2020) Missionoriented innovation systems. Environ Innov Soc Transit 34:76-79. https://doi.org/10.1016/j.eist.2019.11.011

Hekkert MP, Suurs RAA, Negro SO, Kuhlmann S, Smits REHM (2007) Functions of innovation systems: a new approach for analysing technological change. Technol Forecast Soc Chang 74:413432. https://doi.org/10.1016/j.techfore.2006.03.002

Holley J (2013) An introduction to network weaving. Network Weaver Publishing, Athens, Ohio

Kieft A, Harmsen R, Hekkert MP (2020) Toward ranking interventions for technological innovation systems via the concept of leverage points. Technol Forecast Soc Chang 153:119466. https://doi. org/10.1016/j.techfore.2018.09.021

Kivimaa P, Boon W, Hyysalo S, Klerkx L (2019) Towards a typology of intermediaries in sustainability transitions: a systematic review and a research agenda. Res Policy 48:1062-1075. https:// doi.org/10.1016/j.respol.2018.10.006

Kivimaa P, Hyysalo S, Boon W, Klerkx L, Martiskainen M, Schot J (2019) Passing the baton: How intermediaries advance sustainability transitions in different phases. Environ Innov Soci Transit 31:110-125. https://doi.org/10.1016/j.eist.2019.01.001

Klein Woolthuis RJA (2010) Sustainable entrepreneurship in the Dutch construction industry. Sustainability 2:505-523. https:// doi.org/10.3390/su2020505

Klerkx L, Leeuwis C (2009) Establishment and embedding of innovation brokers at different innovation system levels: Insights from the Dutch agricultural sector. Technol Forecast Soc Change 76:849-860. https://doi.org/10.1016/j.techfore.2008.10.001

Kuckertz A (2019) Let's take the entrepreneurial ecosystem metaphor seriously! J Bus Ventur Insights 11:e00124. https://doi. org/10.1016/j.jbvi.2019.e00124

Kuckertz A, Berger ESC, Gaudig A (2019) Responding to the greatest challenges? Value creation in ecological startups. J Clean Prod 230:1138-1147. https://doi.org/10.1016/j.jclepro.2019.05.149

Kuckertz A, Wagner M (2010) The influence of sustainability orientation on entrepreneurial intentions - Investigating the role of business experience. J Bus Ventur 25:524-539. https://doi. org/10.1016/j.jbusvent.2009.09.001

Kukk P, Moors EHM, Hekkert MP (2015) The complexities in system building strategies - the case of personalized cancer medicines in England. Technol Forecast Soc Chang 98:47-59. https://doi. org/10.1016/j.techfore.2015.05.019

Lakoff G (2010) We are the polar bears: What's wrong with the way that the environment is understood. In: Rowley S, Phillips R (eds) From hot air to happy endings: How to inspire public support for a low carbon society. Green Alliance, London, pp 12-15

Lakoff G, Johnson M (1980) Metaphors we live by. University of Chicago Press, Chicago

Lamberson PJ, Page SE (2012) Tipping points. Q J Polit Sci 7:175-208. https://doi.org/10.1561/100.00011061

Loorbach D, Wittmayer J, Avelino F, von Wirth T, Frantzeskaki N (2020) Transformative innovation and translocal diffusion. Environ Innov Soc Transit. https://doi.org/10.1016/j.eist.2020.01.009

Luhmann N (1995) Social systems. Stanford University Press, Stanford

Lundvall B- $\AA$, Vang J, Joseph KJ, Chaminade C (2009) Innovation system research and developing countries. In: Lundvall B- $\AA$, Joseph KJ, Chaminade C, Vang J (eds) Handbook of innovation systems and developing countries: building domestic capabilities in a global setting. Edward Elgar, Cheltenham, pp 1-30
Meadows DH (1999) Leverage points: places to intervene in a system. The Sustainability Institute, Hartland

Meadows DH (2008) Thinking in systems: a primer. Earthscan, London

Milligan K, Schwab N (2017) The inner path to become a systems entrepreneur. Skoll Foundation: https://skoll.org/2017/03/27/theinner-path-to-become-a-systems-entrepreneur/. Accessed 5 June 2020

Milligan K, Schweer Rayner C, Thorogood C, Bonnici F, Saez K (2017) Beyond organizational scale: How social entrepreneurs create systems change. World Economic Forum, Geneva, Switzerland: https://reports.weforum.org/schwab-foundation-beyon d-organizational-scale/

Mühlenbein O (2018) Systems change—big or small? Stanford Social Innovation Review: https://ssir.org/articles/entry/systems_chang ebig_or_small. Accessed 5 June 2020

Mulgan G, Leadbeater C (2013) Systems innovation discussion paper. Nesta, London

Newey LR (2018) 'Changing the system': compensatory versus transformative social entrepreneurship. J Soc Entrep 9:13-30. https:// doi.org/10.1080/19420676.2017.1408671

Niosi J, Saviotti P, Bellon B, Crow M (1993) National systems of innovation: In search of a workable concept. Technol Soc 15:207-227. https://doi.org/10.1016/0160-791X(93)90003-7

Ollove M, Lteif D (2017) Integrating systems thinking and storytelling. Form Akademisk 10:1-15. https://doi.org/10.7577/formakadem isk. 874

Patton MQ (2016) The developmental evaluation mindset: Eight guiding principles. In: Patton MQ, McKegg K, Wehipeihana N (eds) Developmental evaluation exemplars: principles in practice. The Guilford Press, New York, pp 289-312

Pyka A (2017) Dedicated innovation systems to support the transformation towards sustainability: Creating income opportunities and employment in the knowledge-based digital bioeconomy. J Open Innov Technol Mark Compl 3:385. https://doi.org/10.1186/s4085 2-017-0079-7

Radosevic S (2010) What makes entrepreneurship systemic? In: Malerba F (ed) Knowledge intensive entrepreneurship and innovation systems: evidence from Europe. Routledge, New York, pp $52-76$

Rakas M, Hain DS (2019) Innovation system research: Where it came from, and what it is now-a bibliometric network analysis. Res Policy 48:103787. https://doi.org/10.1016/j.respol.2019.04.011

Ratten V, Jones P (2019) Transformational entrepreneurship: An overview. In: Ratten V, Jones P (eds) Transformational entrepreneurship. Routledge, London, pp 1-17

Rittel HWJ, Webber MM (1973) Dilemmas in a general theory of planning. Policy Sci 4:155-169. https://doi.org/10.1007/BF01405730

Rogers EM (2003) Diffusion of innovations, 5th edn. Free Press, New York

Rotmans J, Loorbach D (2009) Complexity and transition management. J Ind Ecol 13:184-196. https://doi.org/10.111 1/j.1530-9290.2009.00116.x

Roundy PT, Bradshaw M, Brockman BK (2018) The emergence of entrepreneurial ecosystems: a complex adaptive systems approach. J Bus Res 86:1-10. https://doi.org/10.1016/j.jbusres.2018.01.032

Sarasvathy SD (2008) Effectuation: Elements of entrepreneurial expertise. Edward Elgar, Cheltenham

Schaltegger S, Wagner M (2011) Sustainable entrepreneurship and sustainability innovation: categories and interactions. Bus Strat Environ 20:222-237. https://doi.org/10.1002/bse.682

Schlaile MP, Ehrenberger M (2016) Complexity, cultural evolution, and the discovery and creation of (social) entrepreneurial opportunities: Exploring a memetic approach. In: Berger ESC, Kuckertz A (eds) Complexity in entrepreneurship, innovation and technology research. Springer, Cham, pp 63-92 
Schlaile MP, Urmetzer S (2019) Transitions to sustainable development. In: Leal Filho W, Azul AM, Brandli L, Özuyar PG, Wall T (eds)Encyclopedia of the UN Sustainable Development Goals: decent work and economic growth. Springer, Cham https://doi. org/10.1007/978-3-319-71058-7_52-1

Schlaile MP, Urmetzer S, Blok V, Andersen AD, Timmermans J, Mueller M, Fagerberg J, Pyka A (2017) Innovation systems for transformations towards sustainability? Taking the normative dimension seriously. Sustainability 9:2253. https://doi.org/10.3390/su912 2253

Senge PM (2006) The fifth discipline: The art and practice of the learning organization, revised edn. Currency Doubleday, New York

Shane SA (2003) A general theory of entrepreneurship: The individualopportunity nexus. Edward Elgar, Cheltenham

Short JC, Ketchen DJ, Shook CL, Ireland RD (2010) The concept of "opportunity" in entrepreneurship research: Past accomplishments and future challenges. J Manag 36:40-65. https://doi. org/10.1177/0149206309342746

Stam E, Spigel B (2018) Entrepreneurial ecosystems. In: Blackburn RA, De Clercq D, Heinonen J (eds) The SAGE handbook of small business and entrepreneurship. SAGE, London, pp 407-422

Steward F (2008) Breaking the boundaries: Transformative innovation for the global good. Nesta, London

Stroh DP (2015) Systems thinking for social change: A practical guide to solving complex problems, avoiding unintended consequences, and achieving lasting results. Chelsea Green Publishing, White River Junction, VT

Thompson N, Kiefer K, York JG (2011) Distinctions not dichotomies: Exploring social, sustainable, and environmental entrepreneurship. In: Lumpkin GT, Katz JA (eds) Social and sustainable entrepreneurship. Emerald, Bingley, pp 201-229

Urmetzer S, Schlaile MP, Bogner KB, Mueller M, Pyka A (2018) Exploring the dedicated knowledge base of a transformation towards a sustainable bioeconomy. Sustainability 10:1694. https ://doi.org/10.3390/su10061694
Urmetzer S, Pyka A (2019) Innovation systems for sustainability. In: Leal Filho W, Azul AM, Brandli L, Özuyar PG, Wall T (eds) Encyclopedia of the UN Sustainable Development goals: decent work and economic growth. Springer, Cham https://doi. org/10.1007/978-3-319-71058-7_43-1

Vexler D (2017) What exactly do we mean by systems? Stanford Social Innovation Review: https://ssir.org/articles/entry/what_exactly_ do_we_mean_by_systems. Accessed 5 June 2020

Waddock S (2016) Foundational memes for a new narrative about the role of business in society. Hum Manag J 1:91-105. https://doi. org/10.1007/s41463-016-0012-4

Warnke P, Koschatzky K, Dönitz E, Zenker A, Stahlecker T, Som O, Cuhls K, Güth S (2016) Opening up the innovation system framework towards new actors and institutions. Fraunhofer ISI Discussion Papers Innovation Systems and Policy Analysis No. 49, Karlsruhe, Germany

Westley F (2013) Social innovation and resilience: How one enhances the other. Stanford Social Innovation Review, Summer (sponsored supplement to SSIR), pp 6-8

Westley F, Tjornbo O, Schultz L, Olsson P, Folke C, Crona B, Bodin Ö (2013) A theory of transformative agency in linked social-ecological systems. Ecol Soc. https://doi.org/10.5751/ES-05072-180327

Williamson OE (1985) The economic institutions of capitalism: firms, markets, relational contracting. Free Press, New York

Wood MS, McKinley W (2010) The production of entrepreneurial opportunity: a constructivist perspective. Strat Entrep J 4:66-84. https://doi.org/10.1002/sej.83

York JG, Venkataraman S (2010) The entrepreneur-environment nexus: uncertainty, innovation, and allocation. J Bus Ventur 25:449-463. https://doi.org/10.1016/j.jbusvent.2009.07.007

Publisher's Note Springer Nature remains neutral with regard to jurisdictional claims in published maps and institutional affiliations. 